\title{
Perceptions of factors that affect employability amongst a sample of final-year students at a rural South African university
}

\begin{tabular}{|c|c|}
\hline \multicolumn{2}{|c|}{$\begin{array}{l}\text { Authors: } \\
\text { Tinashe Harry }{ }^{1} \\
\text { Willie T. Chinyamurindi }{ }^{2} \text { (1) } \\
\text { Themba Mjoli }{ }^{1} \text { (1) }\end{array}$} \\
\hline \multicolumn{2}{|c|}{$\begin{array}{l}\text { Affiliations: } \\
{ }^{1} \text { Department of Industrial } \\
\text { Psychology, University of } \\
\text { Fort Hare, South Africa }\end{array}$} \\
\hline \multicolumn{2}{|c|}{$\begin{array}{l}{ }^{2} \text { Department of Psychology, } \\
\text { University of Fort Hare, } \\
\text { South Africa }\end{array}$} \\
\hline \multicolumn{2}{|c|}{$\begin{array}{l}\text { Corresponding author: } \\
\text { Willie Chinyamurindi, } \\
\text { wchinyamurindi@ufh.ac.za }\end{array}$} \\
\hline \multicolumn{2}{|c|}{$\begin{array}{l}\text { Received: } 14 \text { Dec. } 2017 \\
\text { Accepted: } 05 \text { Apr. } 2018 \\
\text { Published: } 30 \text { July } 2018\end{array}$} \\
\hline \multicolumn{2}{|c|}{$\begin{array}{l}\text { How to cite this article: } \\
\text { Harry, T., Chinyamurindi, W.T., } \\
\text { \& Mjoli, T. (2018). Perceptions } \\
\text { of factors that affect } \\
\text { employability amongst a } \\
\text { sample of final-year students } \\
\text { at a rural South African } \\
\text { university. SA Journal of } \\
\text { Industrial Psychology/SA } \\
\text { Tydskrif vir Bedryfsielkunde, } \\
\text { 44(0), a1510. https://doi.org/ } \\
\text { 10.4102/sajip.v44i0.1510 }\end{array}$} \\
\hline \multicolumn{2}{|c|}{$\begin{array}{l}\text { Copyright: } \\
\text { ( ) 2018. The Authors. } \\
\text { Licensee: AOSIS. This w } \\
\text { is licensed under the } \\
\text { Creative Commons } \\
\text { Attribution License. }\end{array}$} \\
\hline \multicolumn{2}{|l|}{ Read online: } \\
\hline 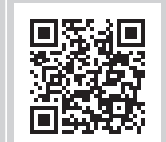 & $\begin{array}{l}\text { Scan this QR } \\
\text { code with your } \\
\text { smart phone or } \\
\text { mobile device } \\
\text { to read online. }\end{array}$ \\
\hline
\end{tabular}

Orientation: The unemployment rate within the South African context is on the rise. Given this, there is a need to understand factors influencing employability amongst a sample of finalyear students in preparation for their transit into the labour market.

Research purpose: The overall objective of this research was to explore final-year students' perceptions of factors that affect employability. This was amongst a sample of students that were enrolled at a rural university in South Africa.

Motivation for the study: Within graduate employability studies, calls have been made to understand the factors around employability especially within a context of high unemployment. This study allows for an understanding of the journey from higher education into the labour market for previously disadvantaged individuals.

Research approach/design and method: An interpretivist, qualitative research approach using an exploratory research design was adopted to explore student perceptions and concerns of employability. Focus-group interviews were used as a data gathering technique amongst 30 final-year students about to exit the university system. Data were recorded, transcribed and processed, and narrative analysis used.

Main findings: Through the analysis, a set of six factors were perceived to influence employability: (1) poor socio-economic status, (2) a poor education system, (3) curriculum issues, (4) the choice of higher education institution and (5) social connections to which the student belongs to.

Practical/managerial implications: Through the identified factors, career counsellors can better understand their clients and those issues that shape their lived experiences. The findings can also assist the provision of better career guidance services.

Contribution/value-add: This study provides an understanding of the complex issues facing potential graduates through lived experiences. It provides an understanding of student perceptions towards employability, which policymakers should consider when addressing the issue of unemployment in the country.

\section{Introduction}

Higher education is essential for economic and social development and meeting the needs of the knowledge economy (Phago \& Thwala, 2015). Higher education can also offer an opportunity to those individuals excluded in the past to compete in the labour market (Chinyamurindi, 2012, 2016a, 2016b). There is thus a need for employability skills, argued to be valuable assets to enhance employability amongst graduates (Davies et al., 2012). Employers also have expectations that graduates will have these employability skills (Artess, Hooley \& Mellors-Bourne, 2017; Tran, 2015).

In South Africa, the government is awarding bursaries to previously disadvantaged individuals to further their studies (Nkosi, 2014). These are individuals who through no fault of their own were affected by apartheid policies (Chinyamurindi, 2012) and are at the centre of efforts to redress past imbalances (Chinyamurindi, 2016a). Subsequently, student enrolment in South African universities has significantly increased (Reddy, Bhorat, Powell, Visser \& Arends, 2016) to reflect this imperative of equity. Sadly, also on the increase is the unemployment rate, especially amongst university graduates (Edayi, 2015; Mncayi, 2016). This has resulted in an oversupply of graduates in the labour market compared to the job opportunities available (Artess et al., 2017; Van Broekhuizen, 2016). 
According to Lourens (2016), higher education provides individuals with subjective contentment and financial benefits. Students cite employment prospects as the primary purpose of pursuing higher education (Wharton, Goodwin \& Cameron, 2014). However, employment prospects of black students are significantly affected by the inadequate schooling system in South Africa (Rogan \& Reynolds, 2016). This often leads to challenges in the system, especially concerning a return on investment based on education inputs (Tholen, 2015).

The concept of employability has received much attention within the extant literature but is in need of further inquiry (Hooley, 2017). Despite differences in the definition of 'employability', mutual ground can be established (Wharton et al., 2014). 'Employability' refers to the competencies and abilities that graduates need to enhance employment opportunities in the labour market, as well as the economic and social development of the country (Jeswani, 2016; Phago \& Thwala, 2015). Higher education is perceived by many people as a pathway to enhance employability (Adrian, 2017; Hooley, 2017). Employability, however, is not a guarantee to secure employment but only enhances employment chances (Lourens, 2016; Paterson, 2017).

An understanding of employability issues provides individuals with an opportunity to be aware of their potential, skills, attitudes and knowledge to become effective citizens and workers (Hooley, 2017). However, student awareness with regards to employability is often overlooked (Tymon, 2013), and this remains an unexplored yet essential perspective in South Africa (Chiwara, Chinyamurindi \& Mjoli, 2017). Calls have been made for studies that focus on understanding both extrinsic and intrinsic goals of students in obtaining employment (Greco, 2016). Further, calls have been made also to understand student perspectives on aspects of employability (Maharaj, 2015) and how this links with skills acquisition (Kaliika, 2011). It is essential to consider such calls and their focus on the student as a key stakeholder in knowledge generation, skills acquisition and utilisation uniquely within the knowledge economy.

\section{Research purpose and objective}

The purpose of this study was to explore final-year students' perceptions of factors that affect employability amongst a sample of students from a rural South African university. Employability affects not only the individuals involved but the country at large. Thus, it is essential to understand how students perceive employability for the benefit of all parties involved. This study was guided by the following question: What factors (given the South African context) affect employability amongst a sample of final-year students at a rural South African university?

\section{Literature review \\ Theoretical lens}

Human capital theory addresses the relationship between higher education attributes and labour market outcomes. Human capital theory posits that investment in education and training leads to returns in private and social lives (Tran, 2015). Social benefits include producing highly skilled individuals for economic development of the country. Private returns are highlighted in higher earnings (Adrian, 2017), significant career progression and broader labour market opportunities. Higher education, therefore, is viewed as a shared investment between the government and individual graduates.

Higher education institutions are under pressure from policymakers to produce employable graduates. However, it remains unclear what constitutes employability and the required graduate employability attributes. Dacre Pool and Sewell (2007) suggested a CareerEDGE model to understand graduate employability, as shown in Figure 1.

Dacre Pool (2016) suggested that missing or overlooking any factor as shown in the figure will result in a negative effect on graduate employability. This model provides guidelines on how employability can be enhanced. Students, however, have high expectations upon completion of their studies, despite missing some of those elements. The perception is that the qualifications will create employment opportunities (Mashigo, 2014; Mncayi, 2016). Employers, however, feel that graduates lack the relevant skills to compete in the open labour market (Goodman \& Tredway, 2016; Paadi, 2014), but the graduates have high expectations (Mncayi, 2016). Subsequently, it is vital that students be realistic about their expectations and what they can offer employers.

\section{Empirical literature}

Tymon (2013) argues that higher education is not a guarantee of a high-paying job, but it enhances employability. Employability is a multifaceted concept that has both internal and external facets (Hooley, 2017). However, it is essential to focus on individual perceptions, which are influenced by both internal and external facets (Rothwell \& Arnold 2007). Internal facets involve aspects such as

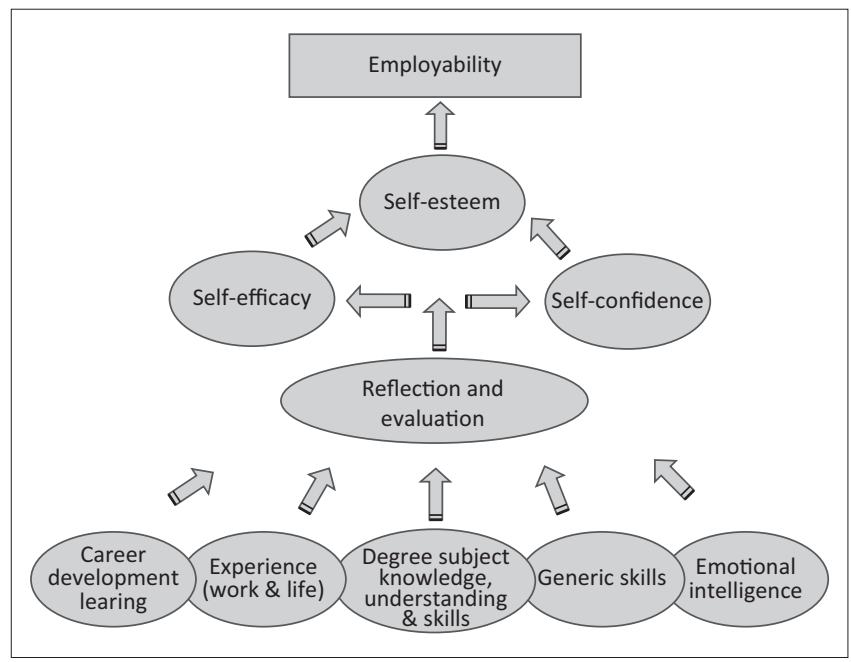

Source: Dacre Pool, L., \& Sewell, P. (2007). The key to employability: Developing a practical model of graduate employability. Education and Training, 49(4), 280. https://doi. org/10.1108/00400910710754435

FIGURE 1: The CareerEDGE model. 
academic performance, students' ambition and confidence. External dimension involves features such as university reputation, the field of study credibility and demand for the field of study (Paterson, 2017).

The employability concept is best understood as being subjective and individual, fortified by concepts of identity and practices (Paterson, 2017). It appears that individual experiences shape the work outcomes of graduates. A previous study by Tomlinson (2007) of final-year undergraduates highlighted that students had developed individualised narratives of their future career progression. Concerning individual perceptions of employability, this shows that students had constructed individual identities. Thus, the perceptions of students can be explained as their beliefs or attitude.

In a study by Mncayi (2016) it was highlighted that graduates, amongst other factors, perceived a lack of labour market knowledge and a lack of self-confidence as reasons for unemployment. Furthermore, most of the graduates resided in areas that were far from economic hubs. Thus, students needed financial resources to access those areas (Council on Higher Education [CHE], 2016; Mlatsheni, 2014; Mncayi, 2016; Reddy et al., 2016). Msimanga (2013) also indicated a lack of connections as a hindrance to employment opportunities.

Moreover, recent graduates have been described as having a strong sense of entitlement and unrealistic view of the job market (Adrian, 2017). Graduates have unrealistic expectations of salaries as well as career progression (Edayi, 2015). The competitiveness of graduates may be enhanced by examining how confident graduates are about their likelihood of being successful in the open labour market (Mncayi, 2016) and factors affecting self-perceived employability (Pitan 2017). Many self-perceptions are associated with actual behaviour (Ferguson \& Bargh, 2004). It is therefore important to understand the perceptions and lived experiences of students about to exit the university system within the context of employment issues.

The higher education sector (like the other levels of education) has been and continues to be affected by the consequences of apartheid (Reddy et al., 2016). Higher education institutions, before democratisation, were divided into historically white and black institutions (Cooper, 2015). Baldry (2013) highlighted that the mergers between white and black universities in South Africa caused differing effects on the ability of graduates to secure employment. Despite the advent of democracy in 1994, significant inequalities still exist in the South African education sector (CHEC, 2016; Kirstein, 2016). Previous findings suggest that to destroy poverty, the education system has to be decolonised (Musitha \& Mafukata, 2018; Van der Westhuizen, Greuel \& Beukes, 2017). Salient findings from previous studies to show the factors that influence employability concerns are illustrated in Table 1.

Based on the findings and debates from previous studies, calls have been made to explore the perceptions of undergraduate students as they are about to transit into the world of work (Wilton, 2008, cited in Paterson, 2017), especially those factors that influence their employability (Koloba, 2017). There is a need to not only consider the perceptions of organisations (Devaney \& Roberts, 2011), but also to understand the concept from the student lens (Archer \& Chetty, 2013). This justification forms the rationale for this study.

\section{Research design \\ Research approach}

The overall objective of this research was to explore finalyear students' perceptions of factors that affect employability amongst a sample of students from a rural South African university. An exploratory study was adopted, as this allowed participants to share their experiences not only

TABLE 1: Summary of findings of factors influencing student employability.

\begin{tabular}{|c|c|c|c|}
\hline Authors & Context method & Research design and method & Findings \\
\hline $\begin{array}{l}\text { Wharton and } \\
\text { Horrocks (2015) }\end{array}$ & $\begin{array}{l}\text { Students' perceptions of } \\
\text { employability ( } 63 \text { participants). }\end{array}$ & $\begin{array}{l}\text { Qualitative approach: } \\
\text { Focus group. }\end{array}$ & $\begin{array}{l}\text { - Perceptions of employability. } \\
\text { - General aspects - marketing oneself, skills for the job. } \\
\text { - Specific aspects - critical thinking, confidence, subject skills. } \\
\text { - Self-belief, self-motivation, enthusiasm. }\end{array}$ \\
\hline Adrian (2017) & $\begin{array}{l}\text { Exploratory study of skills gap } \\
\text { ( } 70 \text { participants). Student and } \\
\text { employer perceptions of } \\
\text { employability. }\end{array}$ & Quantitative approach: Survey. & $\begin{array}{l}\text { - Perceptions and expectations. } \\
\text { - Underestimate importance of social skills. } \\
\text { - Strong expectation of hard and soft skills. } \\
\text { - Universities should put less emphasis on foreign language } \\
\text { proficiency, cultural diversity and community engagement. }\end{array}$ \\
\hline Pitan (2017) & $\begin{array}{l}\text { Student perspectives: Nigeria } \\
\text { and the South African context. }\end{array}$ & In-depth case study approach. & $\begin{array}{l}\text { - Perceptions. } \\
\text { - High level of self-perceived employability. } \\
\text { - High level of self-perceived employability enhances self-confidence. }\end{array}$ \\
\hline Mncayi (2016) & $\begin{array}{l}\text { Graduate perceptions of } \\
\text { unemployment. }\end{array}$ & Quantitative study: Survey. & $\begin{array}{l}\text { - Factors causing unemployment } \\
\text { - Lack of job market information } \\
\text { - Lack of job search skills } \\
\text { - No professional networks } \\
\text { - Mismatch betwing experience } \\
\text { - High cost of job search } \\
\text { - Geographical area one lives in } \\
\text { - No political or personal connections } \\
\text { - Factors not influencing graduate unemployment } \\
\text { - Age } \\
\text { - Race }\end{array}$ \\
\hline
\end{tabular}

Note: Please see the full reference list of the article, Harry, T., Chinyamurindi, W.T., \& Mjoli, T. (2018). Perceptions of factors that affect employability amongst a sample of final-year students at a rural South African university. SA Journal of Industrial Psychology/SA Tydskrif vir Bedryfsielkunde, 44(0), a1510. https://doi.org/10.4102/sajip.v44i0.1510, for more information. 
individually but also in how they fit with a system of factors and issues in an environment. This can assist in arriving at sense-making around an issue that affects the lived experience (Chinyamurindi, 2012, 2016a, 2016b). This method allowed the participants to share how they perceived themselves as students, as well as how they made sense of the transition process into the labour market. Through this method, the researchers were able to understand the perspectives of the participants in relation to the labour market.

\section{Research strategy}

A generic email was sent to 105 final-year undergraduate students whose names were generated from a student database provided by the student registry office of the participating university. A total of 30 students indicated their willingness and availability to participate in the study. A focus group encouraged cooperation and interaction between the participants to obtain shared and common experiences (Wright \& Jeffries-Watts, 2017). The method stimulated students to reflect on their behaviours, attributes, skills, knowledge and experience in relation to their preparedness to enter the labour market (Cole \& Tibby, 2013). This method allowed a deeper understanding of features of employability (Creswell, 2013), as well as identification of student perceptions and reasons behind those perceptions.

\section{Research method}

\section{Sampling and participants}

A total of 30 participants were randomly selected to take part in this study. Most of the students were from low socioeconomic status, owing to the university's social composition. Because of time and budget constraints, the sample was selected using convenience and purposive sampling (Creswell, 2013). Participants, in this regard, had to be finalyear undergraduate students and from the Faculty of Management and Commerce, who were easily accessible to the researchers.

\section{Data collection methods}

Focus-group interviews were conducted with the participants towards the end of their final year of studies. This data collection method was selected as it allowed researchers to obtain multiple perspectives on employability (Eaton, 2017). A focus group was chosen to elicit views that were emotional and spontaneous (Kvale \& Brinkman, 2009). An unstructured interviewing process was adopted to allow a social discussion amongst the participants during the session (Chinyamurindi, 2016a, 2016b, 2017; Levitt et al., 2018).

Before the commencement of the session, the participants were briefed about their responsibilities, rights and expectations around the study. For the study, the exclusion and inclusion criteria were predetermined. Participants had to be final-year undergraduate students from the Faculty of Management and Commerce. The focus-group session was digitally recorded and thereafter transcribed word for word. The researchers also recorded notes during the session.

\section{Entree and establishing researcher roles}

To conduct this study, ethics approval was sought and obtained from the university where this study was conducted. Participants were asked to sign an informed consent before the focus group, which explained confidentiality, voluntary participation and possible benefits. The researchers had to initially understand their own narratives of their experiences as graduates. This allowed the researchers to gain a deeper understanding of the field of experience, specifically the issue of employability (Clandinin, 2013). The process of sense-making was made easier to understand through examining our own experiences, alongside the experiences of the participants (Levitt et al., 2018). The role of the researchers was to record the human experience and understand the meanings that were attached to personal and social experiences by seeking explanations from participants around the experience of unemployment.

\section{Recording of the data Data analysis}

The data analysis and management software QSR NVivo 9 was utilised, because of its effectiveness in dealing with a large amount of text (Bradford, 2013). The focus group data were imported into this software. As adopted in previous studies (e.g. Chinyamurindi, 2016a, 2017; Harry, Dodd \& Chinyamurindi, 2017), this current study also utilised three levels of meaning-making. The first level assisted in understanding employability from the group's perspective. This was done by rereading transcribed notes as well as listening to the audio recording. The 'markers' of the stories were identified through this process (McCormack, 2000, p. 221) and responded to the following question about the discussion: 'what kind of story is this?' (Thornhill, Clare \& May, 2004, p. 188).

On the second level, participants' responses were classified into meaningful categories (Nachmias \& Nachmias, 1996). In the third level, the gathered narrative interpretations and themes were analysed by the researcher (McCormack, 2000). This was made possible by theme identification and use of quotes based on consistencies across narratives of the participants (Rhodes, 2000). This approach allowed understanding of individual sense-making around each story (Chinyamurindi, 2016a), as well as understanding of subsequent intricacies around the lived experience (Maree \& Beck, 2004).

\section{Strategies to ensure data quality and reporting}

Initially, a pilot study was conducted to ensure that all anticipated challenges were addressed before the main study. A prolonged engagement between the researchers and participants was established to build trust between the parties (Creswell, 2013). Participants were given the option to participate in the study. This was to ensure that the session involved participants who were genuinely willing to contribute to the study. Data collection triangulation was also applied by using focus groups and observation for consistency 
of findings. All the data from the session were transcribed within $24 \mathrm{~h}$ of completion session. The researchers used research triangulation to reduce the inherent bias of a single source (Hadi, 2016). Finally, the researchers ensured that the data analysis served the purpose of the inquiry.

The defining feature of qualitative research is the absence of numbers (Levitt et al., 2018). The findings of this study were presented using semi-quantification terms (e.g. many, most, some, several) (Neale, Miller \& West, 2014). This allowed the researchers to suggest a vaguely distinct range of numbers using the above terms. Such type of semi-quantification allowed the researchers to underline consistencies and peculiarities within the data (Neale et al., 2014). However, this does not mean that the findings can be generalised beyond the study sample.

\section{Research results and findings}

From the data analysis, a set of six factors were perceived to influence employability based on the lived experiences of the students: (1) their poor socio-economic status, (2) a poor education system, (3) curriculum issues, (4) the choice of higher education institution and, finally, (5) the social networks the student belonged to. A summary of these factors is presented in Table 2, including how they influenced employability with the illustrating quotes.

\section{Poor socio-economic status}

As the university under study was in a rural area, most of the students who participated in the research cited coming from a low socio-economic background. Subsequently, most of the participants highlighted that their background played a major role in choices around their education and career paths. Participants cited the experience of a family expectation that after graduation they would take care of their families. This expectation created pressure on the individual and their lived experience, including the prospect of securing employment. However, participants in the study were also honest, stating that most of their parents or guardians were not aware of the labour market realities. Hence, it became difficult for them to explain to their families. One of the participants noted:

'I am feeling pressure to find a job early, the pressure that I am getting from my family and friends that studied at TVET Colleges who engaged in practical work and I am stuck with theory.' (Participant 4)

As the participants were from previously disadvantaged backgrounds, most of them were exposed to a poor education system, especially those who grew up in the rural areas, which were most of the participants.

\section{Poor education system}

Most of the participants faced difficulties in trying to adapt to higher education learning, as the moderating language in higher institutions was English. For example, one of the participants explained that most rural schools conducted their classes in the local language. Hence, it became a major challenge for the participants to start using English:

'The other challenge is when you are moving from rural schools then you come here at university; the language becomes a problem because you are used to being taught mathematics in Xhosa - even the English is taught in Xhosa. So you find it becomes a challenge for us, as we have to learn how to write in English.' (Participant 7)

This transition resulted in participants struggling to cope with higher education studies because of a limited understanding of the English language. A limited understanding meant that the participants took longer to understand various concepts in lectures. This resulted in participants having to repeat modules, which in turn extended their study periods. The language had a negative effect on the employability of the participants.

Not only does the language affect employability, but also the participants cited the lack of career counselling services in the high schools they attended. Coming from rural areas, the participants were not exposed to career counselling and guidance to assist them in making decisions about their careers. Participants ended up registering for qualifications without receiving adequate guidance and knowledge about the qualifications. The participants not only 'lack knowledge about the qualifications' but of the 'labour market realities'. One of the participants who was registered for a qualification in Industrial Psychology espoused a:

'... lack of knowledge, for example, Industrial Psychology it is a scarce skill, and now when it comes to looking for careers you find that the only career that you do is HR, of which we do not pursue other options.' (Participant 20)

Not only did this participant not know about Industrial Psychology as a field of study but did not know what one had to do to become a registered Industrial Psychologist. This was a sentiment that was shared by most of the participants who were enrolled for the same qualification.

\section{Curriculum issues}

The way the curriculum was designed was perceived as not allowing the students to gain the relevant skills to compete in the labour market. Participants felt that curriculum mainly focused on the theoretical component of the qualification, neglecting the practical aspect. Participants expressed that they were unprepared for the world of work. One of the participants narrated it as follows:

'We have degrees in which students are going for placement, but when it comes to us, as commerce students, you find that it's difficult because there is no practical to practice the knowledge we have acquired here.' (Participant 15)

Because of a lack of practical training, participants resorted to changing degree programmes, mostly to the Post-Graduate Certificate in Education (PGCE). The participants were not 
TABLE 2: Summary of findings of factors influencing student employability and quotes.

Pactor

Poor education system

Curriculum design

Higher education institution type

Higher institution type is a major factor in South Africa in how one is perceived in participants. the labour market.
The South African education system is affecting many studen especially those who are from rural areas.

Illustrating quotes
Background played a major
role in the decision making of th

- 'Back home our parents expect us to find work so that we can look after them. They do not have the money for us to continue studying.'

- 'All the parents will be happy if you want to further your education, but the problem comes back to us; we are old enough now, we are starting to see that the situation is not good at home and I bet $75 \%$ of us are having children; they are suffering back at home.

- 'I am feeling pressure to find a job early ... pressure that I am getting from my family and friends that studied at TVET Colleges, who engaged in practical work and I am stuck with theory.'

Moderating language:

- 'The other challenge is when you are moving from rural schools then you come here at university, the language becomes a problem because you are used to being taught mathematics in Xhosa - even the English is taught in Xhosa. So you find it becomes a challenge for us as we have to learn how to write in English.'

Lack of career counselling (both at high school and tertiary level):

- 'In high school, we did subjects such as physical science, but when we came here we were put in ... economics and business management, and we had to learn that.'

- 'We do not have knowledge about the other options.'

- 'Lack of knowledge - for example, Industrial Psychology ... is a scarce skill, and now when it comes to looking for careers you find that the only career that you do is HR, of which we do not pursue other options.'

Lack of practical aspect in commerce programmes:

- I think now we are busy on the theoretical part of the business [rather] than to implement the business part ... which ... we have acquired here at this university. For example, we have degrees in which students are going for placement, but when it comes to us as commerce students you find that it's difficult because there is no practical to practice the knowledge we have acquired here.'

- 'Students from other institutions are engaged in practical ... work placements; here at this university we are busy cramming doing the theoretical part only. Of which now when it comes to the field, [the] theory part yes it is needed, but how do you do your job if you have never engaged in the practical part?'

- 'We are not doing practicals because our curriculum does not allow us to engage in practical [work].'

Change of degree programmes:

- 'We are scared to go to the labour market and expose our skill, so I think now this is a challenge. That's why you find many people [who] want to do PGCE.'

- 'Regarding opportunities, with PGCE you do practical and go to work. It is the government that places

you.'

- 'So we need to do the PGCE so that we can be placed and go back home and feed our families and take our children to school:

Type of institution:

- 'This rural environment has not made us ready, regarding inferiority, because this institution is [a] black-dominated institution. You know when you take a student from Wits and compare them with a student from this institution; when you compare [these] two you will find that your level of knowledge is different.'

- 'We have a passion for studying because many people from other institutions are undermining our degree because we are studying at UFH.'

Location of the institution:

- 'The environment makes you ready; this rural environment has not made us work ready.'

- 'A black student at Wits probably faces the same difficulties as a black student at this institution, but the environment in which a black student operates at in Wits is more enabling regarding opportunities. Students in urban areas have more opportunities than rural area students.'

- 'It is difficult to scan the market from where we are located because it is a rural area.'

Work readiness:

- 'I am ready because I will be qualifying as soon as I complete my studies. Obtaining a degree will make me ready.'

- Most of the participants were not ready for the labour market, which was expressed by quotes such as 'confused, at crossroads, feeling I have to move forward even though I do not know even where I am going'

- 'Since I am doing business management I expected at least to have that knowledge, broader knowledge about business things and to be able to apply whatever ... I would have learned onto business. I don't have that now because it was very difficult for me to do a business proposal. For me, I can say I am not ready.'

- 'It breaks my heart to spend sleepless nights and be asked for experience.'

- 'When we come here where [we] are diverse, there are guys from other cultures and they are treated differently; cultural differences are affecting how we interact in group discussions. We feel inferior because of where we come from.

- 'I think this goes back to the inferiority complex. All students ... are scared to approach a lecturer or make an appointment with one or two lecturers.'

- 'We do not have that kind of relationships with our lecturers, so you find that the relationship ends

when the lectures end. So you necessarily do not have the heart to go and ask anything else.'

- 'We do not have access to people who have the relevant knowledge of what is out there.'

- 'We do not have access to people who have the relevant knowledge of what is out there.'

- 'I feel like resources and opportunities
that you need to have in South Africa.' only lacking practical skills but were also 'scared' to enter the labour market without the skills; hence the switch to the PGCE. Many opted for this qualification as it involved a practical aspect. Students enrolled in this programme are placed by the government in various schools to gain experience. Most participants, therefore, wanted to complete the qualification, not because they wanted to do the course but out of desperation to provide for the family. One of the participants expressed that 'we need to do the PGCE so that we can be placed and go back home and feed our families and take our children to school'.

\section{Perceptions around the higher education institution}

Participants further articulated that the higher education institution they attended was a major factor in South Africa in determining how an individual was perceived in the labour market. The participants mentioned that they felt 'inferior' to other students who were studying at more affluent universities, as they were studying at a university perceived to be disadvantaged. Participants indicated that the 'level of knowledge' between students from different institutions was different. Subsequently, the participants 
perceived themselves as being 'undermined' in the labour market because they were holders of qualifications from these disadvantaged institutions.

In addition to the type of institution, participants also mentioned the location of the institution as deterring their employability prospects. Participants were in consensus that the environment played a role in how one competes in the labour market. Studying in a rural area limited chances of 'scanning the labour market' and receiving various opportunities. Being in a rural environment, the participants felt that they were 'not work ready'. One of the participants expressed this perception as follows:

'A black student at Wits probably faces the same difficulties as a black student at a rural university like ours, but the environment in which a black student operates at in Wits is more enabling regarding opportunities. Students in urban areas have more opportunities than us rural area students.' (Participant 6).

There were mixed emotions with regards to work readiness. A few of the participants believed upon completion of their qualifications they would be 'work ready'. It appears that some of the participants valued a mere qualification as enough to make them work ready. As explained in the following statement, 'I am ready because I will be qualifying as soon as I complete my studies. Obtaining a degree will make me ready'.

Nonetheless, most of the participants expressed that despite being on the verge of completing their degrees, they were still not prepared to enter the labour market. This was expressed by statements such as 'confused, at [a] crossroads and feeling I have to move forward even though I do not even know where I am going'. Such feelings were attributed to a lack of work experience, a practical component in their studies and a lack of social networks.

\section{Social connections}

Most of the participants expressed that social connections had become a major role player in the labour market. However, the participants did not have those networks to assist them with employability. Participants consequently expressed that they were not experiencing the labour market the same way as the other students. This was expressed by one of the participants as follows: 'I feel like resources and opportunities are there, but they are hard to get because of the connections that you need to have in South Africa'. Also, because of an 'inferiority complex' and 'society backlash', participants did not receive proper guidance from lecturers or relevant people in the job market.

Most of the participants did not perceive higher education as a way to enhance their employability. Because of various factors discussed above, participants felt discouraged about their future careers. Many of the participants enrolled in tertiary studies aiming to secure employment as soon as they obtained their qualifications.

\section{Discussion Outline of the findings}

The overall objective of this research was to explore final-year students' perceptions of factors that affect employability amongst a sample students from a rural South African university. Factors including socio-economic status, education system, curriculum, higher education institution and social connections were all found and illustrated as influencing employability. Participants associated their employability or the lack of it with these factors.

\section{Relating the main findings to the literature}

It appears that the findings of this study are in support of the existing literature on perceptions of students towards employability. Many of the participants enrolled in tertiary studies to obtain employment. Previous studies noted that students enrolled in higher education to obtain employment (Greco, 2016; Hooley, 2017; Paterson, 2017; Wharton et al., 2014). However, the participants of the current study struggled to access the labour market because of their location (CHE, 2016; Mncayi, 2016; Reddy et al., 2016). Career development opportunities were limited for the participants as they were in a rural area where there were limited (or no) employers to offer them opportunities.

Many of the participants were from poor socio-economic backgrounds. This can be attributed to the availability of bursaries for people from poor socio-economic backgrounds (Nkosi, 2014; Reddy et al., 2016). Despite investments in improving the education system, education quality remains indefinable. Hence, the poor education system is negatively affecting the future employability of the participants (Rogan \& Reynolds, 2016).

A great challenge for the participants was the whole education system. Despite several policy changes in the education system, a division between privileged and under-privileged universities still exists (CHE, 2016; Kirstein, 2016; van Broekhuizen, 2016). As was reported in other studies (CHE, 2016; Mlatsheni, 2014), most of the participants in this study were exposed to poor education quality as they hailed from poor socio-economic backgrounds. The research participants cited that because of the history of the institution, as well as the perception of the outside world, they were at a disadvantage in the labour market (CHEC, 2016; Kirstein, 2016; Rogan \& Reynolds, 2016). Given such negative perceptions, participants struggled to secure employment. Because of the poor education system, the participants were unprepared to compete in the open labour market.

Furthermore, most of the participants expressed that they lacked relevant social connections to navigate the labour market. This is in support of previous studies (CHE, 2016; Msimanga, 2013), which highlighted that white students have better networks than black students. Individuals without social connections are likely to struggle in the labour market (Jackson, 2014). A lack of influential 
social connections may result in a lack of labour market information, underemployment and unemployment. Without these social connections, participants will probably struggle to obtain career development opportunities. This will result in a negative effect on the employability of the participants.

Participants further cited that they lacked work readiness because of the curriculum, which was more theoretical. This was in support of previous studies, which cited that the curriculum was the major factor leading to a lack of work preparedness (Tomlinson, 2007; Tymon, 2013; Vatiswa, 2014). Some of the participants had high expectations of obtaining employment with a mere qualification (Adrian, 2017; Mashigo, 2014). This is regardless of a lack of practical work experience (Mncayi, 2016), and some felt qualifying would entitle them to various employment (Adrian, 2017). They disregarded the fact that a qualification only enhances employment prospects (Lourens, 2016; Paterson, 2017). As outlined in the CareerEDGE model, participants lacked some of the elements such as career development learning, work experience and generic skills (Dacre Pool, 2016). Further to that, the participants lacked self-esteem, self-confidence and self-efficacy owing to their previously disadvantaged backgrounds. The participants were thus unemployable as they only had theoretical knowledge (degree-specific knowledge).

\section{Practical implications}

It appears most of the students showed a lack of relevant labour market knowledge and displayed a lack of confidence. Thus, it is imperative that the students receive support to gain significant work experience. The perceptions of students can be explained as their beliefs or attitude. Thus, higher education institutions should try to instil new beliefs and attitudes towards careers. Previously disadvantaged universities (like the one in this study) should endeavour to re-design their curriculum to enhance graduate employability (Musitha \& Mafukata, 2018; Van der Westhuizen et al., 2017). Although this does not lead to employment, it increases employment prospects for the students (e.g. Lourens, 2016; Paterson, 2017). It is also important to revisit the whole education system to ensure the goals are aligned. Increasing the education quality from schooling improves how students view the labour market. Furthermore, students should receive adequate career counselling to assist them in making informed career decisions. The government should also continue attempting to redress past imbalances to ensure all students, regardless of race, are exposed to similar experiences.

\section{Limitations of the study and future research areas}

This study focused on students at a rural university in South Africa, and the findings may not apply to other universities. Generalisability is limited as the whole sample was from one institution and one faculty. A variation of experiences could have been recorded had other institutions been incorporated in the study. Although enlightening, the findings of this study may not be generalised to other students who are enrolled at other universities classified as disadvantaged, or any other population of students in South Africa. Thus, future studies should utilise samples from several historically disadvantaged institutions. Comparative studies should also be conducted amongst students enrolled in: (1) different institutions; (2) different modes of learning and (3) geographical contexts. It is also imperative to understand employers' perceptions towards aspects of employability and future research can explore such perceptions.

\section{Conclusion}

Post-apartheid has seen many black students enrolling in higher education. Inequality in the labour market, however, continues to prevail. This has resulted in limited employment opportunities, unemployment and underemployment. This study contributes to understanding students' perceptions of employability. By understanding these perceptions and factors, policymakers can develop policies that will cater to the needs of such students.

\section{Acknowledgements}

The authors acknowledge the feedback from the three anonymous reviewers.

\section{Competing interests}

The authors declare that they have no financial or personal relationships that may have inappropriately influenced them in writing this article.

\section{Authors' contributions}

T.H. collected and analysed the data. He was responsible for writing the first two drafts of this article. W.T.C. and T.M. supervised T.H. in his PhD studies. W.T.C. and T.M. also oversaw the data analysis and writing of the article.

\section{References}

Adrian, M. (2017). Determining the skills gap for new hires in management: Student perceptions vs employer expectations. International Journal of Innovation Education and Research, 5(6), 139-147.

Archer, E., \& Chetty, Y. (2013). Graduate employability: Conceptualisation and findings from the University of South Africa. Progressio, 35(1), 134-165.

Artess, J., Hooley, T., \& Mellors-Bourne, R. (2017). Employability: A review of the Literature 2012-2016. York: Higher Education Academy.

Baldry, K. (2013). Graduate unemployment in South Africa: Prevalence, characteristics and perceived causes. Masters dissertation. Johannesburg, South Africa: University of the Witwatersrand.

Bradford, J. (2013). A qualitative exploration examining the enhancement of students personal and professional development through an employability focused curriculum. Doctoral dissertation. Liverpool, England: Liverpool John Moores University.

Chinyamurindi, W. T. (2012). Stories of career change amongst distance learners in South Africa. South African Journal of Human Resource Management, 10(2), 1-11. https://doi.org/10.1177/0081246315623662

Chinyamurindi, W. T. (2016a). Using narrative analysis to understand factors influencing career choice amongst a sample of distance learning students in South Africa. South African Journal of Psychology, 46(3), 390-400.

Chinyamurindi, W. T. (2016b). A narrative investigation into the meaning and experience of career success: Perspectives from women participants. South African Journal of Human Resource Management, 14(1), 1-11. https://doi.org/ 10.4102/sajhrm.v14i1.659 
Chinyamurindi, W. T. (2017). The role of information management in project management success: Narratives from entrepreneurs operating within the South African construction industry. South African Journal of Information Management 19(1), 1-9. https://doi.org/10.4102/sajim.v19i1.811

Chiwara, J. R., Chinyamurindi, W. T., \& Mjoli, T. Q. (2017). Factors that influence the use of the Internet for job-seeking purposes amongst a sample of final year students in the Eastern Cape Province of South Africa. South African Journal of Human Resource Management, 15, 1-9. https://doi.org/10.4102/sajhrm.v15i0.790

Clandinin, D. J. (2013). Engaging in narrative inquiry. Walnut Creek, CA: Left Coast Press.

Creswell, J. W. (2013). Qualitative inquiry and research design: Choosing among five approaches. Thousand Oaks, CA: Sage.

Cole, D., \& Tibby, M. (2013) Defining and developing your approach to employability: A framework for higher education institutions. York: Highe Education Academy.

Cooper, D. (2015). Social justice and South African university student enrolment data by 'race', 1998-2012: From 'skewed revolution' to 'stalled revolution. Higher Education Quarterly, 69(3), 237-262. https://doi.org/10.1111/hequ.12074

Council on Higher Education (CHE). (2016). South African higher education reviewed: Two decades of democracy. Pretoria: CHE. Retrieved from http://www.che.ac.za/ sites/default/files/publications/CHE_South\%20African $\% 20$ higher $\% 20$ education\%20reviewed\%20-\%20electronic_0.pdf

Dacre Pool, L. (2016). Developing graduate employability: The CareerEDGE Mode and the importance of emotional intelligence. In M. Tomlinson \& L. Holmes (Eds.), Graduate employability in context (pp. 317-338). London, UK: Palgrave McMillan.

Dacre Pool, L., \& Sewell, P. (2007). The key to employability: Developing a practical model of graduate employability. Education and Training, 49(4), 277-289. https:// doi.org/10.1108/00400910710754435

Davies, B., Gore, K., Shury, J., Vivian, D., Winterbotham, M., \& Constable, S. (2012) UK Commission's Employer Skills Survey 2011: United Kingdom Results. Retrieved from https://www.gov.uk/government/publications/ukces-employerskills-survey-2011

Devaney, S., \& Roberts, D. (2011). Who gets the jobs? Factors influencing the Management \& Economics, 30(3), 233-246. https://doi.org/10.1080/01446193.2 Management
011.654233

Eaton, S. E. (2017). Research assistant training manual: Focus groups. Calgary, Canada: University of Calgary.

Edayi, J. (2015). Constraints to graduate employment in the city of Johannesburg, South Africa. Masters dissertation. Johannesburg, South Africa: University of the Witwatersrand.

Ferguson, M. J. \& Bargh, J. A. (2004). How social perception can automatically influence behavior? Trends in Cognitive Sciences, 8(1), 33-39. https://doi. org/10.1016/j.tics.2003.11.004

Goodman, S., \& Tredway, G. (2016). Antecedents of perceived graduate employability A study of student volunteers in a community-based organisation. South African Journal of Industrial Psychology, 42(1), 1-10. https://doi.org/10.4102/sajip. v42i1.1315

Greco, L. M. (2016). Professional identification and career goals: Goal setting in the role transition process. Doctor thesis. University of lowa. Retrieved from http:// ir.uiowa.edu/etd/2085

Hadi, M. A. (2016). Ensuring rigour and trustworthiness of qualitative research in clinical pharmacy. International Journal of Clinical Pharmacy, 38(3), 641-646.

Harry, T. T., Dodd, N. M., \& Chinyamurindi, W. T. (2017). Using narratives to understand the motivational factors and experience of being a self-initiated academic expatriate in South Africa. South African Journal of Human Resource Management, 15, 1-9. https://doi.org/10.4102/sajhrm.v15i0.797

Hooley, T. (2017). Climbing the employability mountain. Graduate Market Trends, Spring, 10-11.

Jackson, D. (2014). Factors influencing job attainment in recent Bachelor graduate evidence from Australia. Higher Education, 68(1) 135-153. https://doi.org/ evidence from Australia. High
$10.1007 / \mathrm{s} 10734-013-9696-7$

Jeswani, S. (2016). Assessment of employability skills among fresh engineering graduates: A structural equation modeling approach. The IUP Journal of Soft Skills, 10(2), 7-43.

Kaliika, M. (2011). Perceptions of commerce graduates from a selected higher education institution. Masters dissertation. Grahamstown, South Africa: Rhodes University.

Kirstein, M. (2016). Differences in accounting students' perceptions of their development of generic skills and emotional intelligence in a heterogeneous classroom. Masters dissertation. Pretoria, South Africa: University of Pretoria.

Koloba, H. (2017). Perceived employability of university students in South Africa. Is it related to employability skills? International Journal of Social Sciences \& Humanity Studies, 9(1), 73-90.

Kvale, S., \& Brinkman, S. (2009). Interviews: Learning the craft of qualitative research interviewing. (2nd edn.). Thousand Oaks, CA: Sage.

Levitt, H. M., Bamberg, M., Creswell, J. W., Frost, D. M., Josselson, R., \& Suárez-Orozco, C. (2018). Journal article reporting standards for qualitative primary, qualitative meta-analytic, and mixed methods research in psychology: The APA Publication and Communications Board task force report. American Psychologist, 73(1), 26-46. https://doi.org/10.1037/amp0000151
Lourens, E. (2016). From graduate to employee: Exploring the journeys of first-time entrants into the labour market. Unpublished doctoral dissertation. Cape Town, South Africa: Stellenbosch University.

Maharaj, N. (2015). The graduate employability of ICT Graduates. Masters dissertation. KwaZulu-Natal, South Africa: University of KwaZulu-Natal.

Maree, J. G., \& Beck, G. (2004). Using various approaches in career counselling for traditionally disadvantaged (and other) learners: Some limitations of a new frontier. South African Journal of Education, 24, 80-87.

Mashigo, A. C. L. (2014). Factors influencing work readiness of graduates: An exploratory study. Masters dissertation. Cape Town, South Africa: University of Stellenbosch.

McCormack, C. (2000). From interview transcript to interpretative story: Part 1. Viewing the transcript through multiple lenses. Field Methods, 12(4), 282-297. https://doi.org/10.1177/1525822X0001200402

Mlatsheni, C. (2014). Youth unemployment and the transition from school to work in Cape Town. Doctoral dissertation. South Africa: University of Cape Town.

Mncayi, N. P. (2016). The determinants of employment status of young graduates from a South African University. Masters dissertation. South Africa: North West a South $A$.
University.

Msimanga, T. H. (2013). Determining the factors that affect female unemployment in a South African township. Masters dissertation. Vanderbijlpark, South Africa: in a South
NWU.

Musitha, M. E., \& Mafukata, M. A. (2018). Crisis of decolonising education: Curriculum implementation in Limpopo Province of South Africa. Africa's Public Service Delivery and Performance Review, 6(1), a179. https://doi.org/10.4102/apsdpr. V6i1.179

Nachmias, F. C., \& Nachmias, D. (1996). Research methods in the social sciences. (5th edn.). New York: Worth Publishers.

Neale, J., Miller, P., \& West, R. (2014). Reporting quantitative information in qualitative research: Guidance for authors and reviewers. Editorial Note. Addiction, 109, 175-176. https://doi.org/10.1111/add.12408

Nkosi, B. (2014). High fees keep students out of university. Retrieved from http://www. iol.co.za/news/south-africa/high-fees-keep-students-out-of-university-1.1647818\#. VKZyHU107Gg

Paadi, K. (2014). Perceptions on employability skills necessary to enhance Human Resource Management graduates prospects of securing a relevant place in the labour market. European Scientific Journal Special Edition, 129-143. Retrieved from https://eujournal.org/index.php/esj/article/view/4016

Paterson, R. (2017). Lecturer and student perceptions of employability skills at a transnational university. Qualitative research in education, 6(3), 241-275. https:// doi.org/10.17583/qre.2017.2583

Phago, M., \& Thwala, L. (2015). Baseline study on students' perceptions and attitudes towards the HWSETA Postgraduate Research Bursary Programme. Retrieved from http://www.hwseta.org.za/wpcontent/uploads/2017/01/Baseline_study_on students $\%$ E2\% $80 \% 99$ _perceptions_and_attitudes_towards_the_HWSETA Postgraduate_Research_Bursary_Programme.pdf

Pitan, S. O. (2017). Developing employability in the context of higher education in Nigeria and South Africa: Student perspectives. SRHE Online Webinar: Developing Transferable Skills in Diverse Higher Education Settings. Retrieved from https:// www.acss.org.uk/news/srhe-event-developing-transferable-skills-diverse-highereducation-settings/print/

Reddy, V., Bhorat, H., Powell, M., Visser, M., \& Arends, A. (2016). Skills supply and demand in South Africa. Pretoria: LMIP Publication, Human Sciences Research Council. Retrieved from http://www.hsrc.ac.za/uploads/pageContent/7429/LMIP_ SkillsSupplyandDemand_Sept2016.pdf

Rhodes, H. (2000). Mid-life career change to home-based self-employment in a group of women, Unpublished master's dissertation. British Columbia, Canada: Simon Fraser University.

Rogan, M., \& Reynolds, J. (2016). Study choices and employment transitions among Rhodes Fort Hare university graduates. Human Sciences Research Council, Media Release. Retrieved from http://www.hsrc.ac.za/en/news/view/studychoices

Rothwell, A., \& Arnold, J. (2007). Self-perceived employability: Development and validation of a scale. Personnel Review, 36(1), 23-41. https://doi.org/10.1108/ 00483480710716704

Tholen, G. (2015). What can research into graduate employability tell us about agency and structure? British Journal of Sociology of Education, 36(5), 766-784. https:// doi.org/10.1080/01425692.2013.847782

Thornhill, H., Clare, L., \& May, R. (2004). Escape, enlightenment and endurance: Narratives of recovery from psychosis. Anthropology and Medicine, 11, 181-199. https://doi.org/10.1080/13648470410001678677

Tomlinson, M. (2007). Graduate employability and student attitudes and orientations to the labour market. Journal of Education and Work, 20(4), 285-304. https://doi. org/10.1080/13639080701650164

Tran, T. T. (2015). Is graduate employability the 'whole-of-higher-education-issue'? Journal of Education and Work, 28(3), 1-21. https://doi.org/10.1080/13639080. 2014.900167

Tymon, A. (2013). The student perspective on employability. Studies in Higher Education, 38(6), 841-856. https://doi.org/10.1080/03075079.2011.604408

Van Broekhuizen, H. (2016). Graduate unemployment. Higher education access and success, and teacher production in South Africa. Doctoral thesis. Cape Town, South Africa: Stellenbosch University. 
Van der Westhuizen, M., Greuel, T., \& Beukes, J. W. (2017). Are we hearing the voices? Africanisation as part of community development. Theological Studies, 73(3), 1-9. https://doi.org/10.4102/hts.v73i3.4512

Vatiswa, N. (2014). Is there a gap between graduate competencies and the expectations of the built environment industry in South Africa? Retrieved from http://www.ecsa.co.za

Wharton, C. Y., Goodwin, L. J., \& Cameron, A. J. (2014). Living up to our students' expectations: Using student voices to influence the way academics think about their undergraduates learning and their own teaching. International Journal of Higher Education, 3(4), 72-84. https://doi.org/10.5430/ijhe.v3n4p72
Wharton, C., \& Horrocks, J. (2015). Students' perceptions of employability within their degree programme: Hhighlighting the disparity between what academics believe is included and the student experience. Enhancement and Innovation in Higher Education. Glasgow: 12th Enhancement Themes Conference. Retrieved from http:// www.enhancementthemes.ac.uk/docs/paper/students-perceptions-ofemployability-within-their-degree-programme-highlighting-the-disparity-betweenemployability-within-their-degree-programme-highlighting-the-disparity-betw-wo
what-academics-believe-is-included-and-the-student-experience.pdf?sfvrsn=6

Wright, T., \& Jeffries-Watts, S. (2017). Does it do what it says on the tin? - Evaluation of an established UK university employability enhancement award. Journal of Teaching and Learning for Graduate Employability, 8(1), 152-171. https://doi. Teaching and Learning for Graduate
$\mathrm{org} / 10.21153 /$ itlge2017vol8no1art654 